\title{
PENGGUNAAN BERBAGAI WADAH UNTUK PEMBUDIDAYAAN IKAN HIAS AIR TAWAR
}

\author{
Darti Satyani*) dan Bambang Priono**) \\ *) Balai Penelitian dan Pengembangan Budidaya Ikan Hias \\ Jl. Perikanan No. 13, Pancoran Mas, Depok \\ E-mail: publikasi.bppbih@gmail.com \\ *) Pusat Penelitian dan Pengembangan Perikanan Budidaya \\ J.. Ragunan 20, Pasar M inggu, Jakarta Selatan 12540
}

\begin{abstract}
ABSTRAK
Bisnis ikan hias memiliki prospek yang sangat menggiurkan, tidak perlu modal besar dan dalam membudidayakannya tidak memerlukan keterampilan khusus serta pasarnya pun terbilang cukup mudah, terutama di kota-kota besar. Untuk mendapatkan hasil budidaya ikan hias yang baik dapat dilakukan dengan selalu menjaga kualitas dan kuantitasnya. Dalam menjaga kualitas dan kuantitas tidak terlepas dari cara budidaya ikan hias yang dilakukan. Budidaya ikan hias dapat menggunakan wadah dari berbagai jenis selama tidak bocor. Wadah budidaya yang sering digunakan untuk ikan hias adalah akuarium, kolam tanah, bak semen, kolam terpal/plastik, bak fiber glass dengan ukuran yang beragam. Agar wadah berfungsi dengan baik antara lain adalah wadah harus dapat menampung air dengan baik, mudah dikelola dan tidak atau bukan berasal dari bahan yang dapat mempengaruhi kehidupan ikan.
\end{abstract}

\section{KATAKUNCl: wadah budidaya, air, fungsi wadah}

\section{PENDAHULUAN}

Bisnis ikan hias memiliki prospek yang sangat menggiurkan, tidak memerlukan modal besar dan dalam membudidayakannya tidak memerlukan keterampilan yang khusus serta pasarnya pun terbilang cukup mudah, terutama di kota-kota besar (NAFED, 2006). Selain itu, usaha budidaya ikan hias tidak membutuhkan lahan yang luas dan dapat dilakukan oleh setiap anggota keluarga dalam jangka waktu yang relatif singkat. Jenisjenis ikan hias yang dapat dibudidayakan, antara lain jenisjenis ikan siklid, platis, lemon, cupang, black ghost, manvis, palmas, guppy, diskus, oscar, dan lain sebagainya (Satyani et al., 2007). Cara membudidayakan ikan hias dapat bersifat tradisonal, semi-intensif ataupun secara intensif dengan sarana dan prasarana yang beragam, tergantung kemampuan finansial yang menjalaninya.

Untuk mendapatkan hasil budidaya ikan hias yang baik dapat dilakukan dengan selalu menjaga kualitas dan kuantitasnya. Dalam menjaga kualitas dan kuantitas tidak terlepas dari cara budidaya ikan hias yang dilakukan. Oleh karena itu, dalam kegiatan budidaya ikan hias perlu diperhatikan beberapa, salah satu di antaranya adalah air media. Dalam budidaya ikan hias, air merupakan media yang sangat penting dan mutlak diperlukan (Alderton, 1997). Oleh karena itu, penggunaan air harus benar-benar sesuai dengan kebutuhan hidup ikan, baik kualitas maupun kuantitasnya. Air yang bersih dan tidak mengandung bahan pencemar merupakan media yang sangat baik untuk kehidupan ikan. Agar penggunaan air efisien dan selalu terjaga kualitas dan kuantitasnya, maka diperlukan wadah yang memenuhi syarat untuk segala aktivitas ikan selama dalam masa pembudidayaannya.

Kebanyakan ikan hias memiliki ukuran yang kecil, dengan demikian wadah yang digunakan untuk pemeliharaannya pun harus berukuran kecil pula. Penggunaan wadah untuk budidaya ikan hias tidak memerlukan tempat yang besar dan luas seperti halnya ikan konsumsi. Dengan demikian, ruangan atau wadah yang digunakan dapat menghemat tempat. Sesuai dengan namanya, maka ikan yang digunakan sebagai penghias ruangan atau tempat yang dapat dipandang mata dengan baik dan menyenangkan. Untuk itu, dalam budidaya dan pemeliharaan ikan hias tersebut, wadahnya harus benar-benar mudah dikontrol agar ikan yang dipelihara tetap berkual itas baik. Budidaya ikan hias dapat menggunakan wadah dari berbagai jenis selama tidak bocor (Sakurai et al., 1990). Wadah budidaya yang sering digunakan untuk ikan hias adalah akuarium, kolam tanah, bak semen, kolam terpal/ plastik, bak fiber glass dengan ukuran yang beragam. Selain itu, juga dapat dimanfaatkan barang-barang bekas yang tidak bocor dan dapat ditambal dengan ukuran dan diameter yang beragam ukurannya. Wadah budidaya ikan 
sistem airnya ada yang mengalir dan ada yang tergenang. Wadah pembudidayaan ikan hias ini terdiri atas wadah perawatan induk, pemijahan, penetasan telur, pendederan, pembesaran, dan penampungan hasil. Apapun wadah yang digunakan tentunya fungsi dari wadah harus diperhatikan dengan baik dan benar. Ada beberapa syarat agar wadah berfungsi dengan baik antara lain adalah wadah harus dapat menampung air dengan baik, mudah dikelola, dan tidak atau bukan berasal dari bahan yang dapat mempengaruhi kehidupan ikan.

Saat ini alternatif wadah dari plastik sebagai wadah untuk budidaya khususnya ikan hias juga sudah banyak digunakan. Berbagai variasi dalam bahan maupun bentuk mulai dari yang pabrikan atau cetakan sampai pada yang buatan sendiri banyak dijumpai pada tempat-tempat budidaya ikan hias.

\section{Persyaratan Wadah untuk Budidaya Ikan Hias}

Banyak alternatif wadah yang dapat digunakan untuk budidaya ikan hias, namun sebaiknya wadah tersebut memenuhi kriteria dan persyaratan sebagai berikut:

\section{Wadah Tidak Bocor}

Untuk dapat menampung air maka wadah tentu harus mampu menerima beban berat air yang akan digunakan. Hal ini tentu saja harus diperhitungkan konstruksi dari wadah, seperti rangka wadah, ketebalan wadah, bentuk, dan bahan pembuatnya. Hal lain yang perlu diperhatikan adalah wadah harus tidak bocor agar air yang ditampungnya tidak sampai habis. Kebocoran atau rembesan air harus selalu diperhatikan dan dijaga agar volume air tidak cepat berkurang. Berkurangnya air dalam wadah untuk pemeliharaan ikan hias akan sangat mempengaruhi kualitas ikan yang dipelihara, gampang stres, terkena penyakit, dan kemungkinan mengalami kematian (Alderton, 1997).

\section{Bahan Wadah Tidak Mempengaruhi Kehidupan Ikan}

Beberapa bahan yang dapat mempengaruhi kehidupan ikan, misalkan bahan dari besi atau logam yang nantinya akan berkarat, bila terkena air akan berpengaruh pada kualitas air, sekaligus pada kehidupan ikannya.

\section{Mudah Dikelola}

Sebaiknya wadah untuk memelihara ikan utamanya budidaya mudah dikelola, artinya orang mudah dalam menangani ikan di dalamnya (Lesmana \& Dermawan, 2001) misalnya kemudahan untuk mengganti air, maka wadah harus dapat dengan mudah dimasuki selang sipon, atau pada kolam konstruksi dibuat agar mudah dalam memasukkan dan mengeluarkan airnya. Demikian pula dalam mengambil ikan di dalamnya, sebaiknya wadah mudah pula dimasuki serokan. Akuarium susun yang terlalu rapat mengakibatkan kesulitan untuk memasukkan serokan atau selang air atau pekerjaan dalam membersihkan atau menangkap ikan.

\section{Kuat dan Tahan Lama}

Bahan untuk wadah budidaya ikan sebaiknya kuat dan tahan lama. Walaupun daya tahan ini sangat relatif, yang jelas paling tidak harus tahan sampai ikan dapat dipanen. Akan lebih baik bila wadah juga kuat dan tahan terhadap lingkungan misalkan angin maupun hujan dan panas. Kolam yang berada di luar (outdoor) harus dibuat dengan sistem yang dapat menghindari air berlebih atau meluber saat hujan dengan membuat saluran limpasan, bisa juga dengan memberinya naungan agar air hujan tidak masuk.

\section{Jenis-Jenis Wadah untuk Pembudidayaan Ikan Hias}

\section{Akuarium}

Di Indonesiakan dari kata "Aquarium" yang berasal dari bahasa Latin yaitu aqua yang berarti air dan rium yang berarti tempat, sehingga dapat didefinisikan sebagai "tempat ikan, tanaman, dan organisme air untuk dilihat". Pertama kali istilah "aquarium" digunakan oleh orang Inggris, Gosse (1853) untuk menyebut wadah atau bak yang transparan untuk memelihara binatang air. Walaupun dipercayai dalam sejarahnya yang pertama kali memelihara ikan dalam wadah adalah Bangsa Mesir kuno, yang kemudian diikuti oleh Bangsa Roma, dan akhirnya tersebar ke Timur Jauh. Bangsa Cina melanjutkan tradisi ini dan memasyarakatkannya sampai sekarang (Axelrod et al., 1995).

Saat ini teknologi akuarium berarti atau pada prinsipnya merupakan masalah teknik memelihara organisme air dalam bentuk hidup. Teknik ini meliputi penyediaan air, monitoring kualitas air, maupun memberikan perlengkapan seperti alat resirkulasi, filtrasi, sinar UV, dan lain sebagainya. Teknologi modern telah memberikan banyak tuntutan dalam kualitas, stabilitas, dan kesinambungan dalam konstruksi dan perlengkapan akuarium misal pada netralitas untuk air tawar atau air laut, keamanan agar tidak pecah, kemudahan dalam perawatan dan warna, pengurangan dalam refraksi cahaya dan sebagainya. Ada berbagai tipe akuarium yang ditentukan oleh bahan dan cara pembuatannya.

Akuarium dengan bahan gelas atau kaca, murah tidak korosif (berkarat) tidak membutuhkan perawatan yang 


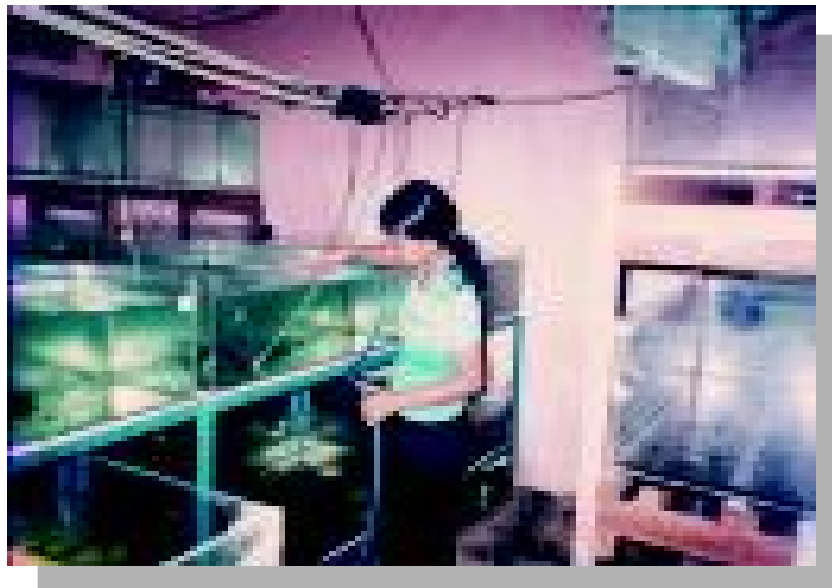

Gambar 1. Wadah akuarium untuk budidaya ikan hias

ekstra (Sakurai et al., 1990). Mudah dibersihkan sehingga bagus untuk pemeliharaan ikan, larva, menetaskan telur (produksi), juga untuk karantina, dan pengobatan ikan.

Akuarium dengan bahan dari gelas atau kaca sangat umum digunakan dalam pemeliharan dan budidaya ikanikan hias. Wadah ini sangat bagus karena selain mudah dibuat juga mudah dalam pengelolaannya, karena ikan mudah dilihat dari luar, sehingga lebih mudah lagi untuk memonitor ikan di dalamnya. Akuarium juga tidak sukar dibuat, dapat disusun sehingga menghemat tempat. Dapat dipindah-pindahkan sesuai tempat dan selera. Penempatannya yang di dalam ruangan juga membuat kondisinya lebih terkontrol. Ukurannya bervariasi tergantung dari peruntukan dan kemauan pemakai. Ketebalan akuarium tergantung dari ukurannya makin besar tentunya harus dibuat makin tebal agar kuat menyangga air di dalamnya. Cara membuat akuarium cukup mudah yaitu dengan menyiapkan potongan kaca sesuai dengan ukuran yang dikehendaki, kemudian dapat dilem

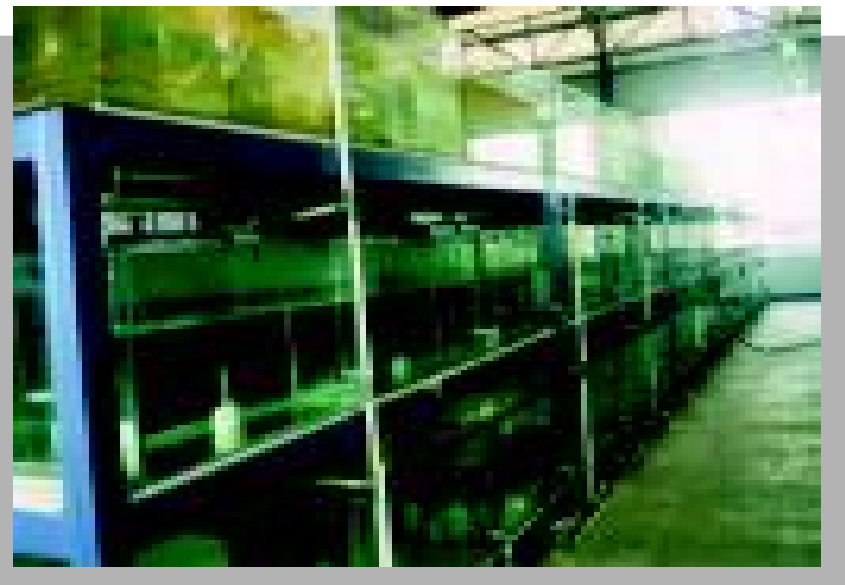

dengan lem kaca yang juga banyak dijual di toko-toko bangunan. Hanya untuk akuarium dengan bentuk tertentu misal yang bulat hanya bisa dibeli karena harus dicetak dan biasanya pabriklah yang bisa mencetaknya.

Akuarium dengan bahan akrilik lebih bagus, bentuk dapat variatif, tahan pecah, dan ringan. Kekurangannya adalah mudah tergores, dan karena biasanya buatan pabrik ukuran harus dipesan. Hanya saja akuarium ini harus hatihati dalam membersihkannya karena mudah tergores. Kendala dalam pembuatan akuarium adalah dalam biaya pembuatan atau harganya yang cukup mahal, selain itu, apabila rusak atau pecah sulit untuk diperbaiki dan tidak dapat digunakan lagi.

\section{Bak fiber glass}

Bak atau wadah yang terbuat dari bahan fiber glass banyak digunakan dalam laboratorium-laboratorium penelitian dan para pengusaha/pedagang baik yang memiliki farming besar atau kecil. Bak dari bahan fiber
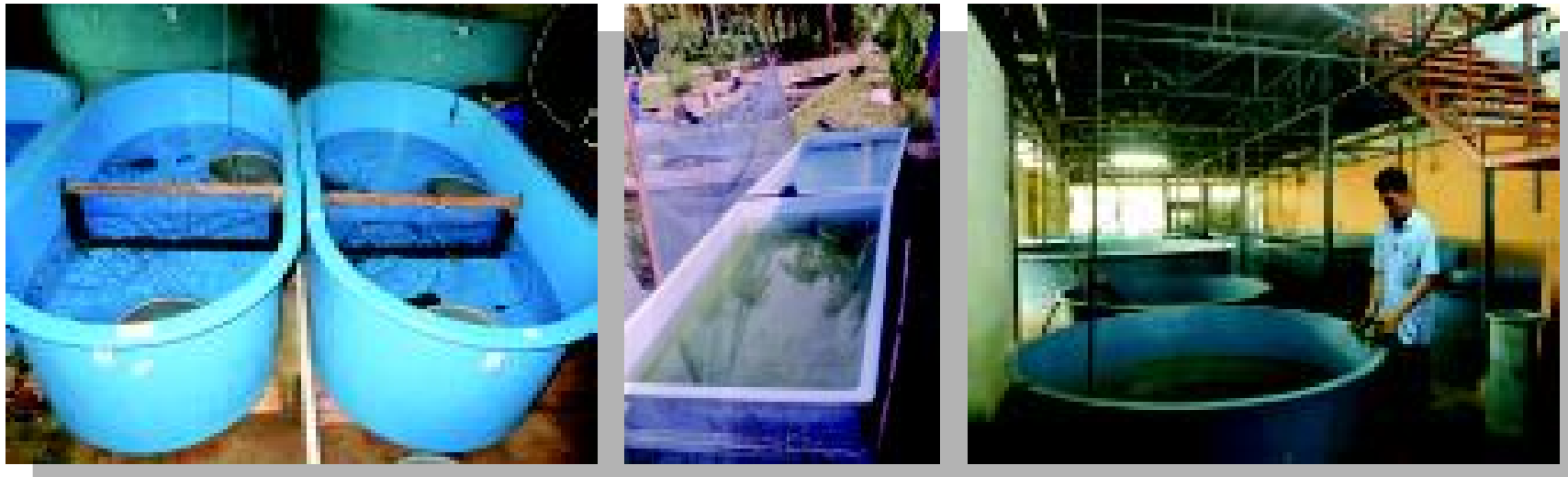

Gambar 2. Bak fiber glass yang banyak digunakan untuk wadah budidaya ikan hias, bentuknya dapat oval, persegi panjang, ataupun bulat 
glass ini sangat bagus untuk pembudidayaan ikan hias, selain kuat, awet, juga suhu air dalam bak pada umumnya relatif stabil (Mills, 1986). Dengan demikian akan sangat mendukung kehidupan ikan yang dipeliharanya. Bak fiber glass dibuat dengan cara dicetak sehingga harus dipesan dari pabriknya. Sangat tahan lama tidak mudah pecah tetapi harganya juga amat mahal. Bak fiber glass biasanya juga cukup ringan sehingga mudah dipindahkan.

\section{Kolam Tanah}

Kolam dari tanah merupakan tempat atau wadah budidaya yang paling tua digunakan oleh manusia, untuk wadah pembudidayaan ikan hias atau ikan konsumsi hampir di seluruh penjuru dunia. Umumnya, digunakan untuk ikan-ikan yang berukuran yang lebih besar, seperti ikan koi, ikan belida atau ikan konsumsi. Kolam tanah yang banyak digunakan untuk pemeliharaan ikan hias pada umumnya untuk memelihara induk-induk ikan yang lebih besar, seperti balashark, koi, atau beberapa catfish besar (Lesmana \& Dermawan, 2001). Ikan-ikan berukuran sedang dapat juga dipelihara dengar kolam tanah, namun pada umumnya para pembudidaya menempatkannya ke dalam jaring atau hapa.

Kolam tanah sangat ideal untuk wadah pembudidayaan ikan hias karena selain banyak mengandung unsur hara dan pakan alami yang sangat penting bagi kehidupan ikan, juga memberikan nuansa alami dan memberikan keleluasaan ikan untuk bergerak bebas. Namun demikian banyak kelemahan dari kolam tanah saat ini, karena air yang masuk ke kolam apabila jauh dari sumbernya biasanya kualitasnya sukar dijaga. Utamanya dalam hal bahan cemaran yang masuk. Hama ikan juga sering banyak dijumpai di kolam-kolam tanah. Belum lagi karena kolam tanah berada di luar rumah kondisi cuaca yang kadang tak bersahabat (panas dan dingin) susah untuk dikontrol.
Beberapa hasil penelitian menunjukkan bahwa ikan hias mempunyai kemampuan hidup pada lingkungan yang beragam. Lingkungan hidup ikan yang sangat mempengaruhi adalah air, suhu, derajat keasaman $(\mathrm{pH})$, kesadahan air, kandungan oksigen terlarut, dan kecerahan. Untuk membudidayakan ikan hias haruslah sesuai dengan kondisi lingkungan air di sekitar kita. Lingkungan air yang ideal bagi ikan hias rata-rata adalah untuk suhu air $24^{\circ} \mathrm{C}$ $30^{\circ} \mathrm{C}$, pH 6-7, oksigen terlarut $>3 \mathrm{mg} / \mathrm{L}$, dan kecerahan air 30-60 cm. Sumber air untuk budidaya ikan hias antara lain berasal dari air tanah, air sungai, dan air PAM. Jenisjenis air tersebut harus diendapkan dahulu minimal 1224 jam sebelum dipakai agar kandungan oksigen terlarutnya cukup dan gas-gas yang lain hilang. Untuk membuat $\mathrm{pH}$ yang sesuai dengan kehidupan ikan hias dapat dilakukan dengan memberikan kapur pertanian atau kapur tohor dengan dosis secukupnya agar air tidak terlalu asam/basa. Kesadahan air menunjukkan adanya kandungan mineral seperti kalsium, magnesium, dan seng dalam air. Tingginya kesadahan sangat dipengaruhi oleh kondisi sekitar, seperti jenis tanaman sekitar sumber air dan mikroorganisme. Kandungan nitrit yang terdeteksi dalam air, biasanya berasal dari sisa pakan, kotoran ikan, lumut, tanaman mati yang terdekomposisi dalam siklus nitrogen. Kandungan nitrit berpengaruh terhadap kesehatan yang berakibat pada pertumbuhan dan perkembangan ikan.

\section{Kolam Semen/Beton}

Sangat bagus dan banyak digunakan dalam budidaya ikan hias. Sangat praktis dan efisien karena pembuatannya juga tidak susah dan harganya juga tidak terlalu mahal. Selain itu, kolam semen juga awet, dan mudah dibersihkan. Tidak ada aturan dalam ukuran dan bentuknya. Bisa digunakan untuk hampir pada semua ukuran ikan, baik yang kecil maupun besar. Larva pun
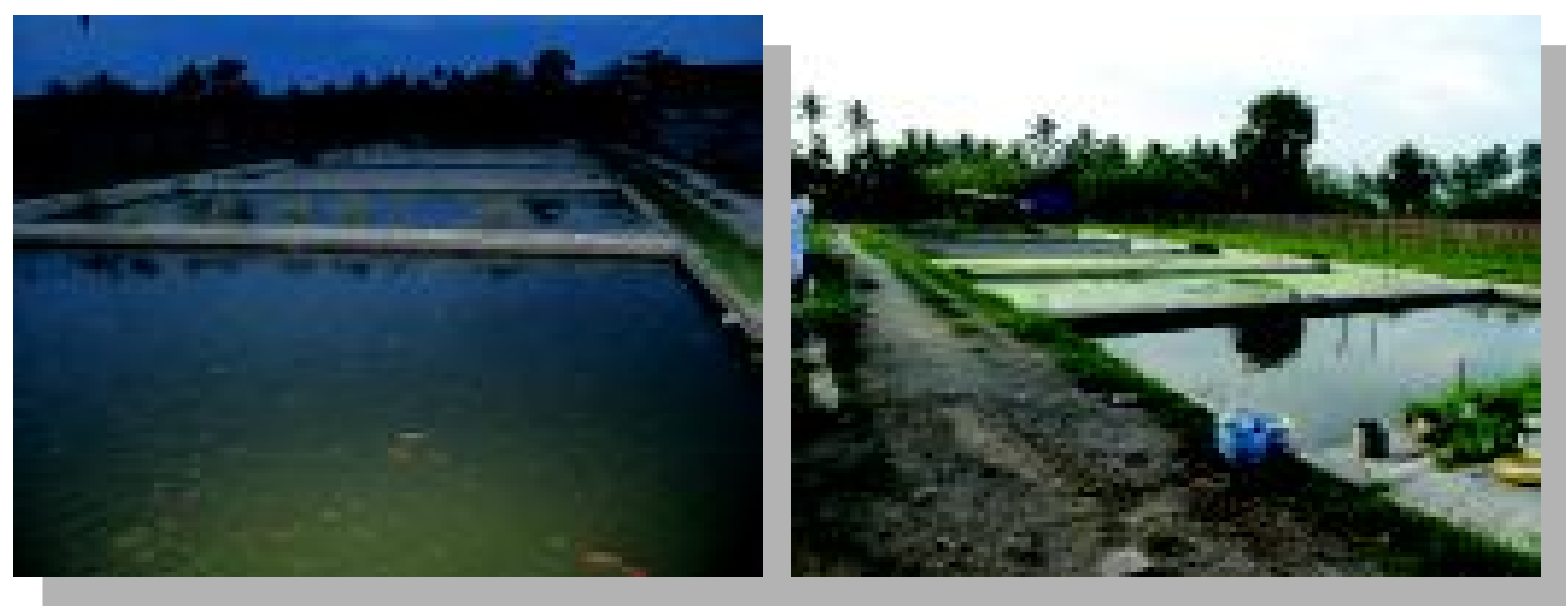

Gambar 3. Kolam tanah yang disemen di pinggirnya untuk budidaya induk-induk ikan koi dan balashark 

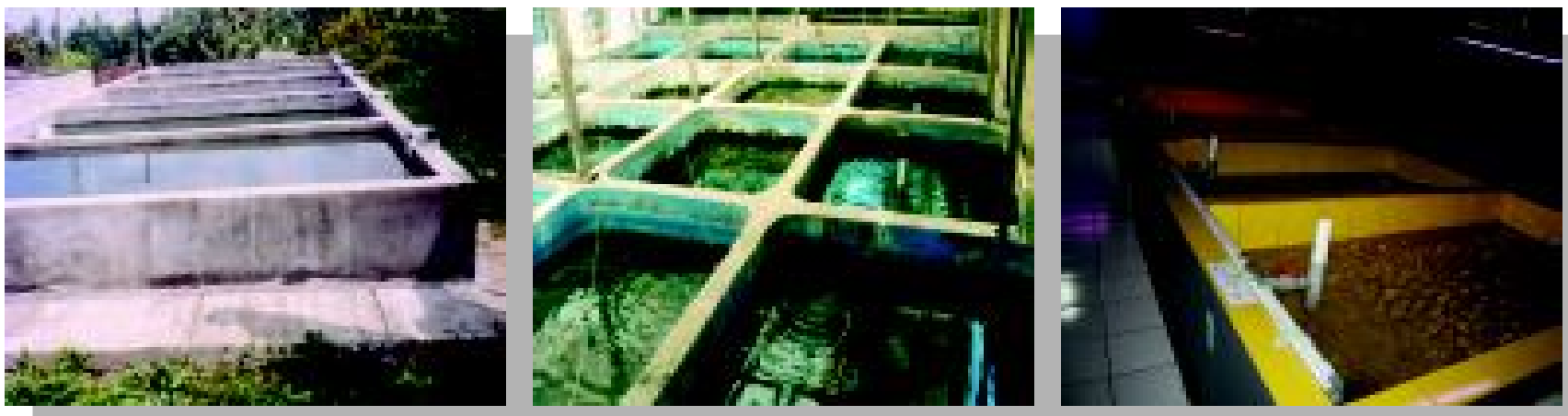

Gambar 4. Kolam/bak semen sangat umum untuk budidaya ikan hias. Bak dari keramik untuk pemeliharaan benih botia berwarna kuning agar warna ikan menjadi lebih bagus (kanan)

sering dipelihara dalam kolam semen. Untuk ikan ukuran kecil biasa digunakan pada pemijahan massal. Kekurangannya adalah bila bocor atau rembes kadang susah untuk dibetulkan atau diperbaiki. Kolam semen juga agak menunggu lama untuk dapat digunakan, karena menunggu air di dalamnya "hidup" yaitu sampai tidak ada efek New Tank Syndrome (sindrom bak baru) yang biasanya pada bak semen ini cukup lama. Kekurangan lain kolam semen yang umumnya dibuat di luar ruangan agak susah dikontrol suhunya dan mudah masuk hama larva capung yang membuat larva ikan banyak mati, terutama bila ada tanaman airnya.

\section{Kolam Plastik}

Merupakan inovasi dari para pembudidaya dalam budidaya ikan, dan baru akhir-akhir ini model kolam ini muncul. Mulai dari yang sederhana sampai yang cukup modern. Yang sederhana terbuat dari lembaran plastik dengan rangka bambu. Plastik dipilih yang tebal dan kuat menahan air. Dasar tanah kolam diratakan dengan baik. Lembaran plastik yang berwarna putih bening karena tipis sehingga rawan bocor. Biasanya petani bila menggunakan plastik ini, dasar tanah sebelumnya dilapisi atau diberi lembaran-lembaran karung beras untuk menjaga atau menghindari adanya barang yang dapat membocorkan. Menggunakan plastik tebal akan lebih aman namun biasanya plastik yang tebal ini ukurannya tidak ada yang lebar, sehingga kolam yang dibuat tidak bisa lebar atau besar juga. Plastik terpal juga bagus karena lebih kuat dan tahan lama tetapi tentu saja harganya lebih mahal.

Inovasi lain adalah kolam plastik dengan rangka dari papan kayu. Karena ukuran papan maksimal adalah empat meter, maka kolam yang dibuat pun tidak bisa lebih dari ukuran itu. Namun umumnya para pembudidaya membuat kolam terutama daerah perkotaan untuk ikan hias ukuran kecil-kecil dengan panjang antara 1-2 m saja. Kolam dari papan ini bisa dibuat dengan alas dari kayu atau bila akan ditempatkan langsung ke dasar tanah bisa dialasi styroform. Bisa juga kolam-kolam ini dibuatkan kaki agar lebih tinggi. Plastik yang digunakan umumnya yang tebal (plastik tenda), agar lebih awet atau tahan lama.

Keuntungan dari kolam-kolam dari plastik ini adalah harganya yang murah, pembuatannya mudah dan cepat, serta dapat langsung digunakan (Lingga \& Susanto, 1986). Dibandingkan kolam dari semen yang mahal, butuh waktu lama dan tentu harganya juga mahal, serta menunggu waktu yang juga cukup lama untuk menggunakannya
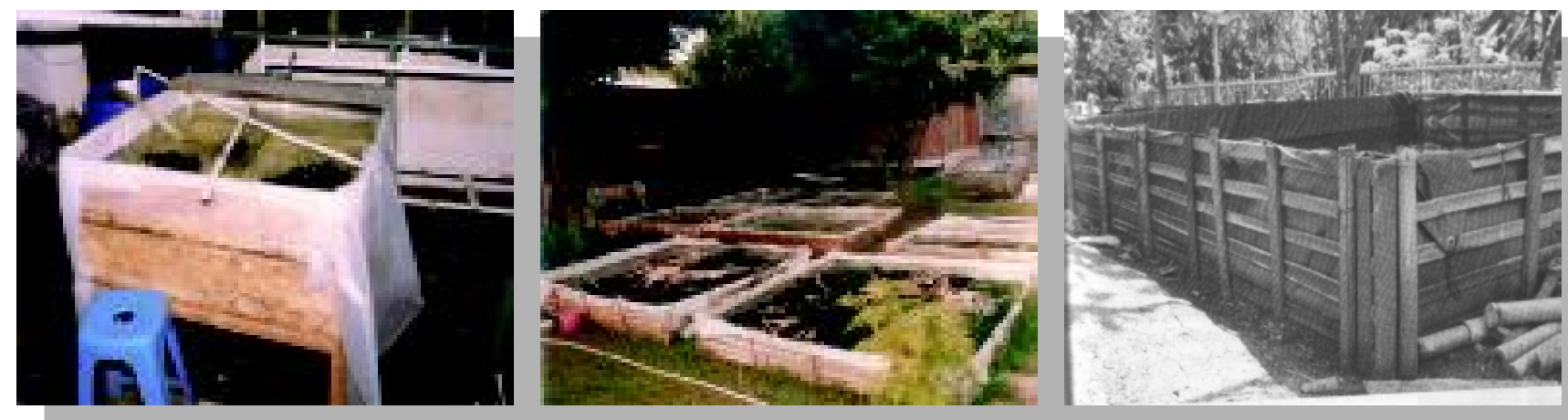

Gambar 5. Bak atau kolam-kolam dari plastik, rangka dapat terbuat dari kayu atau bambu 
kolam plastik lebih efisien. Keuntungan lain yang tidak kalah berharganya adalah kolam-kolam ini tidak merusak tekstur tanah dasar, dan mudah atau dapat dipindahpindahkan sewaktu-waktu seperti halnya bak fiber glass atau akuarium.

Kerugian atau kelemahannya adalah selain tidak tahan lama, bila bocor agak susah menambal atau memperbaikinya, biasanya dapat ditambal dengan lakban. Kolam plastik ini memang bagus bila hanya digunakan dalam waktu singkat, misal untuk memelihara benih-benih atau induk-induk ikan kecil sementara waktu dalam satu atau dua siklus pemeliharaan.

\section{PENUTUP}

Untuk mendapatkan hasil budidaya ikan hias yang baik dapat dilakukan dengan selalu menjaga kualitas dan kuantitasnya. Dalam menjaga kualitas dan kuantitas tidak terlepas dari cara budidaya ikan hias yang dilakukan. Budidaya ikan hias dapat menggunakan wadah dari berbagai jenis selama tidak bocor. Wadah budidaya yang sering digunakan untuk ikan hias adalah akuarium, kolam tanah, bak semen, kolam terpal/plastik, bak fiber glass dengan ukuran yang beragam.

Wadah pembudidayaan ikan hias ini terdiri atas wadah perawatan induk, pemijahan, penetasan telur, pendederan, pembesaran, dan penampungan hasil. Apapun wadah yang digunakan tentunya fungsi dari wadah harus diperhatikan dengan baik dan benar. Ada beberapa syarat agar wadah berfungsi dengan baik antara lain adalah wadah harus dapat menampung air dengan baik, mudah dikelola dan tidak atau bukan berasal dari bahan yang dapat mempengaruhi kehidupan ikan.

\section{DAFTAR ACUAN}

Alderton, D. 1997. The Hamlin book of tropical freshwater fish. Reed international book, Ltd. Singaporen and Toronto.

Axelrod, H.R., Burgess, W.E., Pronek, N., \& Wall's, J.G. 1995. Atlas of fresh water aquarium fishes. Eight edition. TFH Publication, Inc. New York. USA, 335 pp.

Lesmana, D.S. \& Dermawan, I. 2001. Budidaya Ikan Hias Air Tawar, Penebar Swadaya, $159 \mathrm{hlm}$.

Lingga, P. \& Susanto, H. 1986. Ikan Hias Air Tawar, Penebar Swadaya, $236 \mathrm{hlm}$.

Mills, D. 1986. You and your aquarium. Alfred A. Knopf Inc. Toronto. Canada, 75 pp.

National Agency for Export Development (NAFED). 2006. Directory Indonesian Ornamental Fish Exporters. Ministry of Industry and Trade. Republic of Indonesia. Jakarta, 5 pp.

Satyani, D., Sudradjat, A., \& Sugama, K. 2007. Ikan Hias Air Tawar Indonesia. Pusat Riset Perikanan Budidaya. Jakarta, $170 \mathrm{hlm}$.

Sakurai, A., Sakamoto, Y., \& Moro, F. 1990. Aquarium fish of the world. Chronicle Book, San Fransisco, 288 $\mathrm{pp}$. 